\title{
Chaquitaclla, stratégies de labour et intensification en agriculture andine
}

Jean Bourliaud, Raymond Réau, Pierre Morlon et Dominique Hervé

\section{(2) OpenEdition}

Édition électronique

URL : https://journals.openedition.org/tc/911

DOI : $10.4000 /$ tc. 911

ISSN : 1952-420X

Éditeur

Éditions de l'EHESS

\section{Édition imprimée}

Date de publication : 1 septembre 1986

ISSN : 0248-6016

Référence électronique

Jean Bourliaud, Raymond Réau, Pierre Morlon et Dominique Hervé, «Chaquitaclla, stratégies de labour et intensification en agriculture andine », Techniques \& Culture [En ligne], 7 | 1986, mis en ligne le 23 janvier 2006, consulté le 29 septembre 2022. URL : http://journals.openedition.org/tc/911 ; DOI https://doi.org/10.4000/tc. 911

Ce document a été généré automatiquement le 29 septembre 2022.

Tous droits réservés 
Chaquitaclla, stratégies de labour et intensification en agriculture andine

Jean Bourliaud, Raymond Réau, Pierre Morlon et Dominique Hervé 